Busher, H. Hammersley-Fletcher, L. and Turner, C. (2007) Making sense of middle leadership: Community, power and practice, School Leadership and Management 27 (5) pp.405-422

\title{
Making sense of middle leadership: Community, power and practice
}

Hugh Busher, School of Education, University of Leicester

Linda Hammersley-Fletcher, Liverpool John Moores University, Liverpool

Chris Turner, Swansea School of Education, Swansea Institute of Higher Education

\begin{abstract}
This paper argues that studies of middle leaders have focused too much on their functions and characteristics, taking insufficient account of the influence of social and political contexts on leaders' choices of actions. Use of the analytical framework of Communities of Practice (Wenger, 1998) can address this oversight, but it pays insufficient attention to the dynamic processes by which people interact and make meaning of their interactions. The paper concludes that combining existing theories of power with the framework of Communities of practice gives a more complete view of middle leaders at work than current approaches.
\end{abstract}

Keywords: communities of practice, power, teachers' practice, leadership

\section{Introduction}

This paper began as an attempt to survey the existing literature on middle leadership in schools and colleges. It was intended to create a context for several other papers that consider in detail the work of middle leaders in Further Education, Primary Education, and Special Education. It quickly became apparent however that the literature of middle leaders and middle leadership in Primary and Secondary schools is still relatively sparse, if growing, whilst that on middle leadership in FE Colleges and Higher Education is still barely emerging. For this reason we have chosen to focus this paper on Secondary and Primary schools especially in England and Wales where there is some material published, even though it demonstrates a complex diversity of practice. In these countries, Primary schools serve pupils / students of compulsory school age from 5 to 11 years old, while Secondary schools provide education for those pupils from 11 to 16 years old (the official school leaving age in these countries) or 18 years old.

Middle leaders are those people who hold middle ranking posts in the hierarchy of a school, being neither senior leaders, such as Principals or deputy Head-teachers, nor junior staff (although this term is never used) who are teachers, teaching assistants or clerical and site staff with no responsibility for the work of other members of staff, although many, especially teachers are responsible for supervising the work of pupils. In many cases middle leaders are responsible for supervising and working with a group of teachers, and sometimes support staff, too, to construct the teaching and learning of a specified subject of the National 
Curriculum of England and Wales. Hence the name that is sometimes given to such post holders of 'subject leaders'. The size of the groups of teachers and support staff which they supervise varies enormously with the importance of the subject, as specified in the National Curriculum, and the size of the school, as measured by pupil membership of it. Normally Primary schools are considerably smaller than Secondary schools. The National Curriculum is divided into four Key Stages, the first two of which are taught in Primary schools and the second two of which are taught in Secondary schools. The last of these Key Stages is assessed by the official school leaving exam of these countries, the General Certificate of Education (GCSE), while in England the other three are assessed by nationally set Standard Assessment Tests (SATs). Middle leaders also hold posts in the administrative work of a school, such as that of Site supervisor, Senior technician, or Senior Administrative officer (Busher and Saran, 2000).

In Secondary schools middle leaders can be heads of subject departments (groups of teachers who specialise in the teaching of a specific subject in the National Curriculum), or faculties (groups of cognate subject departments, such as Science); leaders of pastoral care (responsible for the well-being of particular groups of pupils, sometimes organised into cohorts of children who enter the school in any one year, known as year groups), or special education; leaders or co-ordinators of cross-curriculum studies; or Advanced Skills Teachers responsible for supporting the development of other teachers in their own school and in linked schools, as well as for teaching their own subject specialism. Bennett et al (2003) point out the wide range of roles and functions middle leaders play. In Primary schools middle leaders are likely to include all the teaching staff (and maybe teaching assistants) who act in different or multiple capacities as a 'middle leader' or a 'follower' (Hammersley-Fletcher and Brundrett, 2005). This paper has chosen to focus its discussions on the work of those middle leaders who might be referred to as subject leaders or heads of subject departments.

In examining the existing literature we noticed that much of it focuses on describing the functions and characteristics of middle leaders, paying very limited attention to the institutional, social and political contexts in which they operate, or, indeed, to the strategies they use or may use to implement policies and actions that allow them to fulfil their functions. Where studies have paid attention to context, they often consider leaders and leadership impersonally, agglomerating evidence from several leaders to paint a broader picture of their work without focusing on the specific lived experiences of particular leaders. There seem to be very few studies that are ethnographic and consider particular leaders in their own social, political and economic contexts. What studies there are tend to construe middle leaders as 'heroes', even if unintentionally, who set out almost single handedly to sustain what is described as good practice. In implementing this they are expected to promote developments in teaching and learning, said to be improvements, that will bring teacher practice in a school more closely in line with central government and / or senior management education policy.

Overlooking the impact of social and political contexts, including those of the internal policies of senior staff in school organisations (Grace, 1995), has seriously weakened the analysis of middle leaders' work. We assert it is the interplay between these contexts and the choices and values of leaders, of whatever level in a school, that offers strong explanations for why modernist enterprises of school improvement and organisational effectiveness are often at best only partially successful. Understanding better this interplay between the agency of individual staff and the societal and organisational systems and structures in which they are located (Giddens, 1984) may also explain why staff resist change as well as how successful practice among them is implemented and sustained. Consequently, it is essential for 
researchers and practitioners to carry out deeper investigations of the complex dynamics of the collectivities or groups of people, with their asymmetrical power relationships, that coalesce into schools or departments, as well as into informal groupings within such institutions. This will give practitioners and policy makers a better understanding how people, such as formally designated (middle) leaders, sustain and develop practice of the very highest quality to meet the educational needs of all the children who attend school (DfES, 2004).

To this end it is argued that the conceptual framework of Communities of Practice (Wenger, 1998), which has been widely applied in business if less frequently in education, offers an important analytical tool for making sense of these dynamics. It offers a framework for thinking about how members of a department or school engage with and construct a community, or the multiple communities that make up a school. These communities, reflect members' individual and collective work-related identities within and as part of particular institutional and socio-political contexts. The pursuit and enactment of self-identity by people is a central aspect of their development (Giddens, 1991). It is part of an interactive process by which people engage with others to construct social systems and structures. It is also the means by which people locate themselves within a society or a community (LaFontaine, 1985; Bourdieu, 1990), as well as being a persona or mask that allows people to play parts ascribed to them in a community (Hollis, 1985). Pupils' and teachers' identities are strongly affected by their histories and social backgrounds (Kearney, 2003). This will, in turn, affect the ways in which they interact with each other and with formally appointed leaders in their communities, such as senior or middle leader.

The collective work-related identity of members of a community is expressed through the culture the members construct. It is an outcome of their interactions. Some people will be more influential (powerful) in its construction than others. It is a means through which members of a community create and sustain their meanings of the purposes of that community, for example, their work. The culture of a community underlies and surrounds all the actions that go on in it, e.g. in schools (Hopkins, 2001). It represents a nexus of particular values and beliefs and is sometimes described as an organisation's or community's 'ethos' or 'atmosphere'. It drives shared patterns of behaviour (Robbins, 2003). It is manifested through the rituals, ceremonies, rules, patterns of action and language of its members (Beare et al., 1989). Mittendorf et al. (2005) refer to the culture of a community as a micro-culture, as distinct from an organisation's culture or a society's culture. He prefers this term to that of a sub-culture because, although an intentionally constructed community, such as a subject department in a Secondary school, is a subgroup of a larger organisation, the culture its members construct is semi-autonomous and not just a subset of a school's organisational culture. In the case of a particular group, such as a subject department in a Secondary school, the identity which teachers' construct as subject specialists is as much related to how they and their colleagues in the department work together and allocate resources as it is to individual members' particular interpretations of what they think being a subject specialist teacher means. Those members whose views depart noticeably from a community's norms are likely to remain or become marginal or peripheral (Lave and Wenger, 1991). It helps to explain why newcomers can face problems when joining a department, especially if they are new subject leaders.

The rest of this paper investigates to what extent the analytical framework of communities of practice, as set out by Wenger (1998), can help make sense of middle leaders working with colleagues in departments in Secondary schools and Key Stage areas in Primary schools. The concept of communities of practice encompasses subtle cultural dynamics such as members' 
perceived social functions and assumptions, rule-making, behavioural norms, boundary and periphery definitions (Wenger 1998:117), and articulated and unarticulated cues about members' status in a particular community. However, it also seems to underplay the importance of dynamic issues of power and ownership (Handley et al., 2006) to the development and processes of such communities. The latter are essential for making sense of the dynamics of decision-making and of the interactions of communities and of their members which shape and are shaped by the actions of leaders. So the last part of the paper explores some of the weaknesses of this framework and suggests by what means its under-6developed understandings of power (influence and authority) (Busher, 2006) can be compensated.

\section{Contextualising middle leadership}

Communities of practice, like departments in Secondary schools, are set in a variety of contexts which help to shape their boundaries and the practices of the members of them. Wenger (1998: 103) points out the importance of these boundaries to communities as they give shape to their members' lives, helping them to position themselves in relation to the variety of other communities of which they have membership (ibid: 158). Some members of communities perform an important function by brokering boundaries between communities (ibid:114). A similar point is made by Glover et al. (1998). One example of this is teachers who work in more than one department and bring the views of each department into the social processes and decision making of the other. Another is of middle leaders who work both within their departments and work at whole school level as a member of a whole-school decision-making forum helping the communities at different levels in the school hierarchy to understand each others' perspectives. However, Wenger (1998: 169) points out that being a member of several communities and working at their boundaries can affect a person's identity as perceived by themselves and by their communities. It helps to explain why middle leaders are sometimes viewed with suspicion by members of their departments who question whether they are really working for the interests of the department or for those of the senior leadership team (Busher, 2005a).

The range of contexts in which communities of practice in education operate is wide ranging. They are constituted by the policy, economic and social contexts of education; the organisational contexts in which the communities are embedded; the epistemological frameworks for making sense of leadership and communities which inform their cultures; and the various technological and pedagogical discourses that suffuse teachers' thinking about teaching, learning and what constitutes subject knowledge. Policy contexts of school organisations are constructed externally by central and local governments and internally by the leaders of institutions (Riley et al, 2000). For example, the remodelling of the school workforce, which began with the introduction of statutory changes to teachers' contracts (DFES 2005a), has the potential to alter dramatically the way in which teachers (and middle leaders) think about their work to introduce what is said to be sustainable and beneficial change (Hammersley-Fletcher and Lowe, 2005). Currently in England the external policy contexts are defined by the Department for Education and Skills (DFES) and its Quangos (Quasi Non-governmental Organisations), such as the National College for School Leadership (NCSL) or the Office for Standards in Education (OFSTED). They are also constructed by the policies of Local Authorities and the institutions which run Academies and Foundation schools. In Wales the external policy context is driven by the Welsh Assembly and its Quangos, notably the ACCAC and Estyn (Her Majesty's Inspectorate for Education and 
Training in Wales). In addition local social contexts are constructed by the civic and social communities within which schools operate and from which their students are drawn.

This paper takes the view that people, not systems are the centres of knowing and the constructors of meaning (Harrison, 1994 p.177). There are various conceptual frameworks for attempting to make sense of this in the dynamic complexities of people's interactions with their contexts and the development of leadership at all levels in educational, public sector and commercial settings (Ribbins and Gunter 2002: 361) as is shown in Table I.

\section{Table I Domains of knowledge for examining leadership in education}

(about here)

In particular, the critical and the humanistic perspectives help to reveal the flows of power through the interactions of the social networks within which people work and live. So they help to make visible the ways in which middle leaders choose to engage in particular actions and the reasons they give for making the choices they do.

Particular socio-economic contexts have a considerable impact on the way in which teachers can teach and manage the behaviour of pupils and on middle leaders' strategies for managing the curriculum or departments. For example, studies in Germany (Baumert and Schumer, 2002), New Zealand (Thrupp, 1999) and England and Wales (Demack, 2000) all point to the socio-economic status of students being a key indicator of academic under-achievement and over-representation in disciplinary confrontations with teachers and headteachers in schools. Such students include those in homes suffering family crises or disturbed social circumstances. A recent report by Shelter found that the impact of homelessness on children's education, health and job opportunities was deleterious (TES, 4 June 2004:4) because such children found it difficult to retain school places or maintain regular attendance. This led to poor performance in their school work. Ethnic background is also an important factor affecting student - teacher relationships and, so, the work of middle leaders. Francis and Archer (2005) comment that pupils of Chinese heritage in England and in some cases of Indian heritage, too, outperform all other groups of students whether they come from advantaged or disadvantaged social backgrounds. DfES (2005b) suggest that some students, often male, from particular ethnic minority groups in England consistently perform relatively poorly academically, although white males from socially disadvantaged backgrounds perform at a similar level. These pupils present particular challenges for communities of teachers and their leaders to resolve.

Knowledge areas, and how they are constituted and re-constituted through time, are also an important context that shape the way subject teachers and middle leaders think about their practice in schools. Constructions of what counts as knowledge in particular subject areas, be it what knowledge is to be included or excluded or how it is to be taught, emerge from changing definitions of the subject area that are asserted by powerful people or groups, such as professional bodies or central government through alterations to the National Curriculum. Knowledge and power are intertwined (Foucault, 1975). Thus as Turner (2005) explains, knowledge areas of different Secondary school departments influence the way in which middle leaders operate because the epistemic communities of which they and their colleagues 
have membership affect the views they hold about appropriate approaches to teaching and learning.

\section{Constructing communities of practice}

Organisations and communities like schools (Sergiovanni, 2001) are built through processes of debate, dialogue and interaction between individuals and between individuals and collectivities, such as departments or groups of students/pupils or, occasionally, groups of parents. These collectivities can be described as communities of practice (Lave and Wenger, 1991; Wenger, 1998) if they coalesce around identifiable practices, such as how to teach or learn a particular subject in the school curriculum.

Practice is seen as the way in which people pursue particular enterprises together in order to achieve success (Wenger 1998: 47). Teachers working together to develop appropriate teaching and learning strategies for their students or pupils, albeit usually under the guidance of designated middle leaders, are an example of such a community. However, such communities need not necessarily be coterminous with the formal groups, such as departments, in a school. They might exist across such departments or reflect the perspectives of an identifiable group of teachers within them. The middle leaders, who are ascribed some formal authority for supervising the work of teachers (Turner, 2005), try to help teachers develop practice that not only reflects the needs of pupils but also the school's curriculum policy, the expectations of senior staff and parents, and the resources available. In England and Wales collaborative approaches to working (Turner, 2005; Hopkins, 2001) between teachers and between teachers and Teaching Assistants (TAs) and other support staff (Busher and Blease, 2000) seem to be the most successful means of constructing development. However formally appointed leaders are also perceived by other staff in a school to have hierarchical authority. For example, in Primary schools, "even within collaborative cultures staff agree that they should ultimately defer to the head" (Hammersley-Fletcher, 2005: 47).

This deference to hierarchically appointed leaders raises questions about how power affects the negotiation of shared meanings between people trying to function effectively together. It is an issue that affects all negotiation, whether or not people are formally co-equal in a community / organisation, since each negotiation is a struggle between participants' values and beliefs, the outcomes of which are shaped by their access to informal as well as formal or bureaucratic sources of power. Negotiation of meaning is central to the way in which people engage with each other to decide what actions to implement in what ways (Wenger, 1998: 52). The latter process includes rules for carrying out action, such as how to mark students' work, and is often manifested through the use of various cultural artefacts to convey values and beliefs, such as the arrangement and display of work on classroom or school noticeboards. Beare et al., (1989) point out that the culture of a community is presented through the artefacts, procedures and language it uses to convey its core values and purposes.

Communities are constructed through people mutually engaging with each other to develop a shared repertoire of actions in pursuit of a shared enterprise (Wenger, 1998: 73), for example teaching a particular school subject or set of skills to children of a particular age. In doing so the members of a community develop a shared history and shared stories about what their community stands for (Kearney, 2003). This influences members' future actions and their responses to new people wanting to join the community, whether it be a student teacher undertaking a teaching practice placement or a new formally designated head of department 
or subject leader joining it. Newcomers to a community or department have to become literate (Street 1994; Gee, 2000) in its practices, values and beliefs in order to be accepted by its members and influence its further development.

People's identities as teachers and leaders are affected by where other members of their communities position them and where they choose to position themselves in relation to the boundaries of each community to which they belong. People who are thought by other members of a community to represent the essence of its practices are perceived as core members of a community (Wenger 1998). However, peripheral activity is valuable to communities, too. Middle leaders, for example, have to link the decision-making of senior management to the decisions and practices in their own departments (Busher et al, 2000; Turner, 2005) but, in doing so, risk having members of their departments question whether they are really part of the department or merely agents of the senior staff. Wenger (1998:120) notes that people who position themselves on the peripheries of several communities risk becoming peripheral to all the communities and not perceived as central or core to any of them. However, the process of brokering between formal and/or informal communities (Wenger, 1998: 108; Glover et al., 1998) helps them to interact successfully with each other, for example by reconciling different approaches to action (Wenger 1998:160). So there is an analytical distinction between people who enact important peripheral functions and people who are perceived as marginal to a community (Wenger, 1998:166). The former may be influential in helping communities to develop and relate to each other but the latter are unlikely to be so.

Within a Secondary school there are likely to be many formal communities of practice (academic departments, clerical departments, senior management teams) with many members being participants in several of them - having membership of multiple communities (Wenger 1998:158), e.g. teachers who teach more than one subject, perhaps moving from one area of a school to another to do so. As they move from one community of practice to another they will encounter the boundaries of the different communities (Wenger 1998: 161) and will have to adapt their practice in appropriate ways for each, rather as pupils do as they move from one subject department to another for different lessons. Although such staff flexibility may make managing the curriculum efficient, people who are peripheral members of communities may not have the same sense of commitment to developing a shared repertoire of successful practice that core members of a particular shared enterprise have (Wenger 1998: 153), say the teaching of Mathematics. Coordinating the work of such colleagues can cause middle leaders considerable difficulties, whether engaging them in consultation and decision making or gaining their full consent to agreed departmental practices, say, of recording pupils' marks on spreadsheets. This problem is often exacerbated by peripheral members of a department experiencing competing demands on their time from different departments. Busher (2005b) described how one teacher, whose teaching room was in a different part of the school from those of the other members of one of the departments of which he had membership, experienced a sense of isolation from consultation and decision making in that department.

The identities of members of communities and their relationships with their communities have a trajectory that is always developing (Wenger, 1998: 154). This begins with the induction of new members into learning particular ways of working (Huysman and van Baalen, 2002), as well as of social and administrative practice. If induction is successful, new members and their community are likely to develop convergent senses of purpose and repertoire, demonstrating shared beliefs, participation, interdependence between practitioners and mutual interpersonal support (Westheimer, 1999). People with power in a community, such as a 
middle leader, are important in facilitating or inhibiting this process of induction since they influence the rules and processes through which new members, such as newly qualified teachers, learn. Wenger (1998: 155) argues that this learning modifies peoples' senses of identity which in turn shapes their relationships within their communities of practice. The extent to which dissent from agreed practices and values is tolerated in a community will depend on how a community's culture is constructed.

The concept of a community of practice has been applied to departments in a Secondary school or to Key stage areas in larger Primary schools, rather than to an entire school, because it is suggested that it is these entities that are likely to display many of the characteristics Wenger (1998:125) considers communities of practice display:

- Sustained mutual relationships

- Shared ways of engaging in doing things

- The rapid flow of information and propagation of innovation

- Absences of introductory preambles in conversations as if each new conversation and interaction were merely the continuation of on going processes

- Very quick setup of a problem to be discussed

- Substantial overlap in participants' descriptions of who belongs

- Knowing what others know, what they can do and how they can contribute to an enterprise

- Mutually defining identities

- The ability to assess the appropriateness of actions and products

- Specific tools, representations and other artefacts

- Local lore, shared stories, inside jokes, knowing laughter

- Jargon and short cuts to communication as well as the ease of producing new ones

- Certain styles recognised as displaying membership

- A shared discourse reflecting a certain perspective on the world

These characteristics encapsulate, 'a community of mutual engagement, a negotiated enterprise, and a repertoire of negotiable resources accumulated over time' (ibid: 126). Such characteristics may well be displayed by small Primary schools. The less that members of a community share such characteristics or engage with each other, the more likely they are to be at best peripheral to a community.

Groups of communities of practice are often drawn together in constellations that form a whole organisation with a common vision, a sense of shared history, a shared environment and personnel practices, and possibly a common location geographically (Wenger, 1998: 129) although Wenger also recognises that communities of practice and constellations can develop in virtual space and in time and space. Although the separate formal communities, e.g. subject departments, within a school may relate to each other through the boundary processes discussed earlier, their interactions are often facilitated by senior or middle leaders of the whole school organisation (constellation of practice) who also link them to the policies and practices of the whole school. This implies that in larger schools teachers' perceptions of their primary community is likely to be the subject area, or Key Stage area, in which they do most of their teaching. Their identification with the whole organisation or with other departments in it is likely to be weaker.

Although communities of practice may emerge through natural social processes, perhaps through the shared interests of staff in the informal organisation of a school (Busher, 2006), 
Wenger (1998: 236) also recognises that communities of practice can be constructed intentionally to meet the needs of a larger organisation. This is clearly seen in schools and colleges where new teaching departments are set up to develop new parts of the curriculum or when teaching departments are brought together into faculties, or large departments are disaggregated into smaller entities in an attempt to meet the demands of educational policies. Middle leaders are key people in helping to draw together the development of these new communities, but are also only one of the several people in that community whose interactions will help to develop it by building its culture (Busher, 2006).

\section{Missing links: where is the critical perspective?}

Understandings of the importance of language and literacies in the development of communities of practice are poorly articulated (Barton and Tusting, 2005) which, they argue, is strange given the importance Wenger places on participation and reification (1998: 63) in the construction of such communities. Both of these processes occur largely through participants' use and development of language, and of literacies that allow them to read and engage with the repertoires of practices and meanings that their colleagues in their several communities of practice, or other members of an organisation, such as the senior staff in a school, construct. The construction of a shared repertoire of practice lies at the heart of members of a community achieving successful outcomes for their particular enterprise. This might be, for example, teachers developing successful learning with their pupils, perhaps in a specific subject in the National Curriculum. Pupils, like school staff, also develop particular uses of language and literacies that affect their capacity to engage successfully with school and with the curriculum. These form part of the social capital (Bourdieu, 1990) they bring to school and are developed through their interactions with their social and school-based communities and their families, their habitus (Bourdieu, 1990). This social capital shapes pupils' views of schooling and their capacity to access the formal school curriculum. For children from different ethnic groups this has a tendency to enhance or diminish their academic achievement (Francis and Archer, 2005, DfES 2005b). For teachers and middle leaders it raises questions about the repertoire of practices they need to develop and the literacies they need to help pupils to learn if pupils are to be successfully integrated and engaged in school.

Equally the analytical framework of communities of practice fails to represent adequately the asymmetrical power relationships that infiltrate and shape all the interactions of people in a school and with a school. None the less Wenger (1998) recognises theories of power as central to social theory (p.14), along with theories of subjectivity and collectivity which are embedded in notions of communities of practice. The interplay of participation and reification in communities of practice of necessity creates acceptance of some values and rejection of others in the micro-cultures of these communities as members negotiate a repertoire of agreed practices for their enterprise. The choice of this repertoire and the values it represents constitutes a series of political decisions, since in making one choice other possibilities are excluded (Ribbins, 1999). Further, not all members of a community are able to assert equal influence on the selection of a repertoire of practice and its associated values. Core members of a community are likely to wield more influence than more peripheral members and, in formal organisations such as schools, formally appointed leaders are likely to have greater bureaucratic authority to control the outcomes of such negotiations than other members of a community in order to keep decisions coherent with the policies of senior staff and / or school governors or central government. 
In not developing explanations for how power flows between members of a community of practice, or between communities of practice, or between a community of practice and its constellation (say, between the practices and policies of a department and those of a whole school), the framework offers little insight into processes of decision- making, especially in hierarchically structured systems such as schools where bureaucratic authority is an important source of power to office holders, subject as subject leaders. Such systems are themselves reified distributions of power that have been constructed through previous or historic negotiations between organisational participants and stakeholders. The lack of robust explanations for the construction and impact of hierarchy and of flows of power, risk making discussion of the negotiation and participation of members in their communities of practice appear bland and non-controversial (which they are not) or to have a false egalitarianism between participants which does not reflect the lived experiences of members of those communities or of the constellations of which they form part.

One way to address this weakness is to elaborate how power flows round groups of people in schools by making use of existing relevant theory about power in and around organisations (Foucault, 1986; Mintzberg, 1986; Ball, 1987; Blase and Anderson, 1995; Bennett, 2001; Busher, 2006). The starting point for this discussion might be that values, which lie at the core of the cultures developed by participants in communities of practice, also lie at the core of how leaders build relationships with their colleagues and students (Hodgkinson, 1991). It led Begley (1999) to consider that the first responsibility of leaders is to reflect on and make explicit their own values, then to consider other people's values, and finally to engage in dialogue with other people to resolve values conflicts.). Leaders who want to sustain school improvement need to build an emancipatory organisational culture while wrestling with ambiguity and work-related disagreements by building, 'a consensus around high order values that members of the school community can relate to and believe in' (West et al., 2000: 40). These values include ethical and transparent approaches to decision-making.

Such values are more likely to be sustained by the values embedded in distributed leadership (Gronn, 2000; Woods et al, 2003) or transformational leadership (Burns, 1978) than by other leadership approaches that are more autocratic or corporate in focus, since they help leaders to foster positive interpersonal relationships and construct a sense of community (Sergiovanni, 2001). They also encourage members of a community to perceive decision-making as a shared activity (Gronn, 2002) even if that sharing is on an unequal basis because of the hierarchical distribution of authority in the formal organisation of a school. In communities where these values sustain trust between members, Smyth et al. (2000) argue that participants, whatever position they hold, are likely to develop a critical dialogue about the development of practices of teaching and learning which will enhance the conduct of their enterprise (Wenger, 1998). Such healthy cultures are likely to develop the positive engagement of staff and pupils with their communities and / or their schools to construct repertoires of practices that meet the variety of learning needs of their pupils inclusively.

Influence and authority are available to leaders at all levels from a variety of sources (Busher, 2006) to implement the values that they and their colleagues in a community think are relevant to the purposes for which they are working in particular socio-political contexts. Blase and Anderson (1995) describe leadership as a use of power over, with or through other people. Middle leaders offer their colleagues and pupils a range of social, symbolic and material resources as sources of power to shape or support their colleagues' actions to develop their own preferred practices within the contexts of the organisational system and processes 
and national and local frameworks of policy (Giddens, 1984). Middle leaders can also use the same sources of power to negate colleagues' actions or to coerce colleagues in various ways to fit in with their preferred scenarios of action when they think it appropriate. How middle leaders enact the functions expected of them by senior and other staff, pupils and parents is framed by the cultures, traditions and histories of the institutions within which they find themselves (Foucault, 1977) and of those other people (students / pupils, parents, support staff, academic colleagues and senior staff) with whom they work.

Access to some sources of authority (power linked to formal organisational processes) is delegated to middle leaders by more senior leaders and school governors allow them to enact their role and functions in a school. The same is true for teachers (Bourdieu and Passeron, 1977). Bureaucratic power, or authority, is manifested through symbolic actions (such as chairing a meeting, or teaching a class) and the control of material resources such as the disposition and allocation of finance, space, time, physical artefacts, and staff. However exercising such authority is unlikely to be particularly successful unless people also make use of personal or professional sources of power (Busher, 2006), too, to negotiate with people and project their vision and values for their communities. As Gibb (1947) pointed out, holding office, having headship, does not of itself give rise to successful leadership unless leaders also make use of a large repertoire of micro-political strategies which draw on a range of formal and informal sources of power (authority and influence). Such sources of power may be socio-emotional, personal (or charismatic), technical or pedagogical (related to teaching and learning), or epistemological (knowledge of knowledge structures and the curriculum, or of organisational systems).

Leaders try to circumvent the dilemmas and social tensions they generate when taking decisions by creating what they claim are rational explanations for and rules to legitimate their decisions and require people to act in particular ways (Lenski, 1986). Bacharach (1983) perceived this as a 'mobilisation of bias' through rules, beliefs and rituals that legitimate only certain courses of action that generally favour the perspectives of dominant leaders or managers in particular situations, whether in the classroom, the subject department, or the school staffroom. Constructing rule frameworks for communities so that their members police themselves (Foucault, 1977) is less corrosive of social cohesion than leaders directly confronting and coercing colleagues or subordinates. Hardy (1985: 390) argues that such use of unobtrusive power creates attitudes among subordinate groups and individuals which allow the powerful to endow their actions or proposed actions with legitimacy in the eyes of those people. Thus members of a community become complicit with their leaders in the surveillance of their own actions, becoming less critical in questioning the extent to which selected action meets the agreed cultural values of their communities of practice or organisations.

\section{Conclusion: Communities of practice a curate's egg?}

The preceding arguments lead to a new theorisation of the realm of the middle (Siskin, 1994) in schools and move beyond the functionalist descriptions and prescriptions that litter much of the literature on leadership. This more complex explanation encapsulates participants' perceptions and conceptualisations of action, peoples' interactions and development, and how they negotiate and enact membership of particular identifiable communities. In these, however, some people have more access to power or authority than others. This allows the 
more powerful to have greater influence than others over the ways in which the culture and practices of a community are shaped and, so, limits the ways in which the identities of participants in those communities may evolve. As people in schools have membership of many communities of practice, sometimes playing a core part in one while playing a peripheral part in another, they have to learn to navigate the boundaries and practices of the different communities in order to construct work-related identities that sustain their positive self-esteem (Benjamin, 2002).

Clearer understandings of the work of middle leaders will come through investigating various aspects of their relationships with other members of their communities of practice. One of these is the construction of a community of practice with colleagues, the cultures of it and the on-going development of repertoires of practice to further its purposes. Another is to investigate the decision-making processes of a community of practice of which a middle leader has membership, including how he/she brokers connections between one community and another in school, or between a community and its constellation of practice (the whole school), or between a community and its relationships with people, such as parents, and communities external to a school. Another aspect of that investigation is how middle leaders support and develop the enthusiasm of teachers to continue with their learning and alter their practices to better meet the changing learning and social needs of pupils. Yet another, is to investigate how middle leaders construct and change their work-related identities when working with their colleagues and how this alters their capacities as middle leaders as well as those of their colleagues. Yet a fourth aspect is to investigate the exercise of power within different communities of practice and how that affects the cultures and repertoire of practices that develop in them. But that needs to be complemented by investigations of the impact of national level policies and local level distributions of wealth and socio-economic status (SES) on those communities and their constellations of practice, such as schools. Such foci for research have clear implications for research methodology and the extensive use of qualitative and ethnographic methodologies.

The analytic framework developed in part by Wenger (1998), offers an important means of making sense of the complexities of the workings of communities of practice in schools, whether formally and intentionally constructed departments, or informally emerging groups of staff, pupils or parents. Consequently it can offer important insights into how leaders of such communities work purposefully with other participants. However because of its inadequate theorising of power and micro-politics in communities of practice, it does not of itself explain adequately how flows of power shape and are shaped by the interactions of participants in their communities in particular socio-political contexts. Nor does it explain how those flows of power shape and are shaped by the changing identities of the members of those communities. Consequently this analytical framework struggles to make sense of how people in a community exert influence to achieve the choice and implementation of particular values and policies that are reified through practices and cultural artefacts of many sorts. For this analytical framework to offer deep insights into the interactions of people as individuals and groups in schools it needs to be complemented by understandings of power that are indicated in the last section of this paper.

\section{References}


Bacharach, S (1983) Notes on a political theory of educational organisations, in A. Westoby (ed) (1988) Culture and Power in organisations, Milton Keynes: Open University Press Ball, S. J. (1987) The Micro-politics of the school London: Methuen

Barton, D and Tusting, K (2005) Introduction in D. Barton and K Tusting (eds) (2005)

Beyond communities of practice: Language, power and social context Cambridge:

Cambridge University Press

Baumert, J and Schumer, G (2002) Family background, selection and achievement: The

German experience Improving Schools 5 (3) pp13 - 20

Beare, H., Caldwell, B., \& Milikan, R. (1989) Creating an excellent school London,

Routledge.

Begley, P. T (1999) Academic and practitioner perspectives on values, in P. T. Begley and P.

E. Leonard (eds) (1999) The Values of Educational Administration, London: Falmer Press.

Benjamin, S. (2002) The micro-politics of inclusive education, Buckingham: Open

University Press

Bennett, N. (2001) Power, structure and culture: An organisational view of school

effectiveness and school improvement, in N. Bennett, and A. Harris, (eds) (2001) School

Effectiveness and School Improvement: searching for the elusive partnership, London:

Continuum

Bennett, N. Wise, C. Woods, P.A. and Newton, W. (2003) Leading from the middle: A review and analysis of the evidence, paper given at the British Educational Research Association Annual Conference, Edinburgh, 14-16 September

Blase, J. and Anderson, G. L. (1995) The Micro-politics of Educational Leadership: From Control to Empowerment, London: Cassell.

Bourdieu, P (1990) The logic of practice, tr. Richard Nice Cambridge: Polity Press

Bourdieu, P. and Passeron, J-C. (1977) Reproduction in Education: Society and Culture, London: Sage

Burns, J.M. (1978) Leadership, London: Harper Row.

Busher, H (2005a) Being a middle leader: exploring professional identities, School Leadership and Management, 25 (1), 137-154.

Busher, H (2005b) The Project of the other: Developing inclusive learning communities in schools Oxford Review of Education 31 (3), 459-477

Busher, H (2006) Understanding Educational leadership: People, power and culture, Buckingham: Open University Press

Busher, H. and Blease, D. (2000) Growing Collegial cultures in subject departments in

Secondary schools: working with Science staff, School Leadership and Management 20

(1): $99-112$

Busher, H and Harris, A. with Wise, C. (2000) Subject leadership for school improvement, London: Paul Chapman

Busher, H and Saran, R (2000) Managing with support staff, in K. Stott, and V. Trafford, (eds) (2000) Partnerships: Shaping the Future of Education London: Middlesex

University Press, pp.203-217.

Demack, S (2000) Social class ethnicity and gender variations in GCSE attainment 1988-1995 paper presented at the British Educational Research Association Annual conference, Cardiff September 2000

DfES (2004) Every Child Matters: Change for Children, London: DfES

DfES (2005a) School Teacher Pay \& Conditions: www.teachernet.gov.uk/doc/8802/20050810 STPCD SECTION 1.doc as accessed in September 2005.

DfES (2005b) Evaluation of Key Stage 3 National Strategy: Proportion of children achieving 5 GCSEs grades A- C, London: DfES 
Foucault, M (1975) Birth of the Clinic: An Archaeology of Medical Perception Translated by A.M. Sheridan New York: Vintage / Random House

Foucault, M (1977) Discipline and Punish: The Birth of the Prison, trans. A. Sheridan, London: Allen Lane

Foucault, M (1986) Disciplinary power and subjection in S. Lukes, (ed) (1986) Power, Oxford: Blackwell.

Francis, B and Archer, L (2005) British - Chinese pupils' and parents' constructions of the value of education British Educational Research Journal 31 (1) 89-108

Gibb, C (1947) The principles and traits of leadership, in C. Gibb, (ed)(1969) Leadership, Harmondsworth: Penguin

Gee, J.P. (2000) New people in new worlds: Networks, the new capitalism and schools, in B. Cope, and M. Kalantis (eds.) Multi-literacies: Literacy, learning and the design of social futures London: Routledge

Giddens, A. (1984) The Constitution of Society, Cambridge: Polity Press.

Giddens, A. (1991) Modernity and self-identity: Self and society in the late modern age Cambridge: Polity Press

Glover, D. Gleeson, D. Gough, G. and Johnson, M (1998) The meaning of management: the development needs of middle managers in Secondary schools Educational Management and Administration 26 (3)181-195

Grace, G. (1995) School Leadership: Beyond Educational Management: An Essay in Policy Scholarship, London: Falmer Press.

Gronn, P (2000) Distributed properties: A new architecture for leadership, Educational Management and Administration, 28 (3), 317-338.

Gronn, P (2002) Distributed leadership as a unit of analysis, The Leadership Quarterly, 13, 423-451.

Hammersley-Fletcher, L. (2005) Distributing Leadership in Primary schools Education 3-13, 33 (2), 46-50.

Hammersley-Fletcher, L. and Brundrett, M. (2005) Leaders on Leadership: the impressions of Primary school headteachers and subject leaders, in School Leadership and Management, 25 (1), 59-75.

Hammersley-Fletcher, L. and Lowe, M. (2005) Remodelling schools - experiences from within 'change teams', Paper presented at the British Educational Research Association Conference (BERA), $14^{\text {th }}-17^{\text {th }}$ Sept, 2005, University of Glamorgan.

Handley, K., Sturdy, A., Fincham, R. \& Clark, T. (2006) Within and Beyond Communities of Practice: Making Sense of Learning Through Participation, Identity and Practice, Journal of Management Studies, 43, 641-653 Retrieved May 17, 2006,

Hardy, C. (1985) The Nature of Unobtrusive Power, Journal of Management Studies, 22 (4), 384-399.

Hodgkinson, C. (1991) Educational Leadership: The Moral Art, Albany: State University of New York Press.

Hollis, M (1985) Of masks and men in M. Carrithers, S. Collins, and S. Lukes, (eds) (1985

The category of the person: Anthropology, philosophy history Cambridge: Cambridge

University Press

Hopkins, D. (2001) School improvement for real London, Falmer Press.

Huysman, M and van Baalen, P (2002) Communities of practice Netherlands: Uitgeverij Boom

Kearney, C (2003) The Monkey's mask: Identity, memory, narrative and voice, Stoke-onTrent, Trentham Books 
LaFontaine, J.S. (1985) Person and individual; Some anthropological reflections in M.

Carrithers, S. Collins, and S. Lukes, (eds) (1985 The category of the person: Anthropology, philosophy history Cambridge: Cambridge University Press

Lave, J and Wenger, E (1991) Situated learning: Legitimate peripheral participation Cambridge: Cambridge University Press

Lenski, G (1986) Power and privilege in S. Lukes (ed) (1986) Power, Oxford: Blackwell Mintzberg, H (1986) Power in and around organisations San Francisco: Jossey Bass

Mittendorf, K., Geijsel, F., Hoeve, A., Laat, M. D. \& Niewenhuis, L. (2005) Communities of practice as stimulating forces for collective learning Journal of Workplace Learning, 18, 298-312.

Robbins, S.P., (2003) Organizational behaviour, $10^{\text {th }}$ Ed. Englewood Cliffs, NJ, Prentice Hall.

Ribbins, P (1999) Foreword in P. T. Begley, and P. E. Leonard, (eds) (1999) The Values of Educational Administration, London: Falmer Press

Ribbins, P and Gunter, H (2002) Mapping leadership studies in Education: Towards a typology of Knowledge Domains, Educational Management and Administration 30 (4), $359-385$

Riley, K.A., Docking, J, and Rowles, D (2000) Caught between local education authorities: Making a difference through their leadership, in K.A. Riley, and K.S. Louis, (eds) Leadership for Change and School Reform London: Routledge Falmer.

Sergiovanni, T. (2001) Leadership: what's in it for schools? London: Routledge Falmer. Times Educational Supplement (TES) (2004) Homeless and helpless TES 4 June 2004: 4 Siskin, L. (1994) Realms of Knowledge: Academic Departments in Secondary schools, London: Falmer Press.

Smyth, J., Dow, A., Hattam, R., Reid, A. and Shacklock, G. (2000) Teachers' Work in a Globalising Economy, London: Falmer Press.

Street, B. V. (1994) Cross-cultural perspectives on literacy, in J. Maybin (ed.) Language and Literacy in social practice Clevedon: Multilingual Matters and Open University Press

Thrupp, M. (1999) Schools Making a Difference: Let's be Realistic! Buckingham: Open University Press.

Turner, C. (2005) How to Run Your Department Successfully, London: Continuum. Wenger, E. (1998) Communities of Practice: Learning, Meaning, and Identity New York, Cambridge University Press.

West, M., Jackson, D., Harris, A. and Hopkins, D. (2000) Learning through leadership, leadership through learning, in K.A. Riley. and K.S. Louis, (eds) (2000) Leadership for Change and school Reform, London: RoutledgeFalmer.

Westheimer, J (1999) Communities and consequences: An inquiry into ideology and practice in teacher's professional work, Educational Administration Quarterly 35 (1), 71-105

Woods, P. A., Bennett, N., Harvey, J.A. Wise, C. (2003) Understanding Distributed Leadership, paper given at the British Educational Association (BERA) Annual Conference, Edinburgh, 11 - 13th September 2003.

Table I Domains of knowledge for examining leadership in education

\begin{tabular}{|l|l|l|l|l|}
\hline Conceptual & Critical & Humanistic & Evaluative & Instrumental \\
\hline $\begin{array}{l}\text { Concerned with issues } \\
\text { of ontology and }\end{array}$ & $\begin{array}{l}\text { Concerned to reveal } \\
\text { and emancipate }\end{array}$ & $\begin{array}{l}\text { Gathers and } \\
\text { theorises from the }\end{array}$ & $\begin{array}{l}\text { Abstracts and } \\
\text { measures the }\end{array}$ & $\begin{array}{l}\text { Provides leaders } \\
\text { with effective }\end{array}$ \\
\hline
\end{tabular}




\begin{tabular}{|l|l|l|l|l|}
\hline $\begin{array}{l}\text { epistemology, and } \\
\text { with conceptual } \\
\text { clarification, and the } \\
\text { complexities that arise } \\
\text { from values. }\end{array}$ & $\begin{array}{l}\text { leaders and } \\
\text { followers from } \\
\text { social injustice and } \\
\text { oppression of } \\
\text { established power } \\
\text { structures }\end{array}$ & $\begin{array}{l}\text { experiences and } \\
\text { biographies of } \\
\text { those who are } \\
\text { leaders and } \\
\text { managers }\end{array}$ & $\begin{array}{l}\text { impact of } \\
\text { leadership } \\
\text { effectiveness on } \\
\text { organisational } \\
\text { outcomes }\end{array}$ & $\begin{array}{l}\begin{array}{l}\text { leadership } \\
\text { strategies to deliver } \\
\text { organisational } \\
\text { outcomes }\end{array} \\
\end{array}$
\end{tabular}

(after Ribbins and Gunter, 2002) 